ŁUKASZ GRZEJDZIAK

ORCID: 0000-0003-0249-7500

Uniwersytet Łódzki

lgrzejdziak@wpia.uni.lodz.pl

\title{
Wpływ na handel między państwami członkowskimi UE jako przesłanka stosowania art. 107 ust. 1 TFUE. Kierunki rozwoju orzecznictwa
}

\begin{abstract}
Abstrakt: Wpływ na handel między państwami członkowskimi UE jest jednym z elementów definicyjnych pojęcia pomocy państwa w rozumieniu art. 107 ust. 1 TFUE. W toku rozwoju judykatury TSUE wykładnia tego warunku ewoluowała. Orzecznictwo stopniowo poświęca jej ocenie więcej uwagi, doprecyzowując znaczenie oraz (nieznacznie) zawężając jej zakres. Ocena spełnienia warunku wpływu na handel wewnątrzunijny stosowana przez TSUE opiera się na analizie podażowej strony rynku - otoczenia konkurencyjnego beneficjenta pomocy. W innym kierunku rozwija się praktyka decyzyjna Komisji. W licznych decyzjach uznawała ona, że środek wsparcia nie stanowi pomocy państwa, ponieważ nie wpływa na handel między państwami członkowskimi UE. Komisja kierowała się tu przede wszystkim argumentem lokalnego zakresu działalności beneficjenta pomocy. Takie podejście, odnoszące się do oceny popytowej strony rynku, choć wprost niesprzeczne $\mathrm{z}$ orzecznictwem TSUE, nie znajduje w nim oparcia.
\end{abstract}

Słowa kluczowe: prawo Unii Europejskiej, reguły konkurencji, prawo pomocy państwa, pojęcie pomocy państwa.

\section{Wprowadzenie}

Wpływ na wymianę handlową pomiędzy państwami członkowskimi UE jest jednym $\mathrm{z}$ elementów konstrukcyjnych pojęcia pomocy państwa w rozumieniu art. 107 ust. 1 TFUE. Podobnie jak jego odpowiednik zawarty w art. 101 i 102 TFUE odgrywa rolę przesłanki jurysdykcyjnej, której spełnienie warunkuje możliwość stosowania europejskich reguł konkurencji. W odróżnieniu jednak od prze- 
słanek stosowania zakazów praktyk ograniczających konkurencję nie rozgranicza pomiędzy sferami stosowania krajowych i europejskich reguł konkurencji, biorąc pod uwagę nieistnienie krajowych systemów prawa pomocy państwa.

Wyróżniane w orzecznictwie jako autonomiczne elementy pojęcia ,pomoc państwa" przesłanki wpływu na handel między państwami członkowskimi i zakłócenia lub zagrożenia zakłóceniem konkurencji często analizowane były przez właściwe instytucje unijne łącznie i w sposób uproszczony ${ }^{1}$. Ostatnie lata rozwoju orzecznictwa i praktyki Komisji Europejskiej (dalej: Komisja lub $\mathrm{KE})$ przynoszą jednak nowe osiągnięcia w tym zakresie, zachęcając do ponownej analizy sposobu wykładni warunku wpływu na handel między państwami członkowskimi UE.

Artykuł skupia się na analizie ewolucji judykatury sądów europejskich i praktyki Komisji w zakresie wykładni warunku wpływu na handel wewnątrzunijny. Jego celem jest identyfikacja tendencji rozwojowych tejże wykładni oraz zarysowanie związanych z tym węzłowych problemów prawa pomocy państwa.

\section{Szeroka koncepcja wpływu na handel wewnątrzunijny}

W pierwszych dekadach rozwoju orzecznictwa sądów europejskich wykładni warunku wpływu na handel między państwami członkowskimi UE poświęcano niewiele uwagi. Było to konsekwencją przyjęcia przez Trybunał, a za nim przez Komisję, koncepcji szerokiego zakresu tego warunku. W wydanym w 1980 roku wyroku w sprawie Philip Morris v. Komisja Trybunał ustanowił obowiązującą do dziś regułę orzeczniczą, wskazując, że handel między państwami członkowskimi zakłócony jest wówczas, ,gdy finansowa pomoc państwa wzmacnia pozycję przedsiębiorstwa w porównaniu z innymi przedsiębiorstwami konkurującymi w handlu wewnątrzwspólnotowym"2.

Aby zatem omawiany warunek został spełniony, beneficjent wsparcia nie musi prowadzić transgranicznej działalności handlowej w ramach terytorium UE. Istotne jest, aby przedsiębiorstwa, względem których pozycja beneficjenta została wzmocniona, w ramach takiego handlu konkurowały ze sobą. Decydujące znaczenie ma więc okoliczność istnienia wewnątrzunijnej wymiany handlowej takimi towarami lub usługami jak te, których oferentem jest beneficjent wsparcia.

${ }^{1}$ Doktryna podkreśla bliską relację treści obu tych warunków; por. m.in. T.M. Rusche et al., State aid, [w:] The EU Law of Competition, red. J. Fall, A. Nikpay, Oxford 2014, s. 1953; oraz K. Bacon, EU Law of State Aid, Oxford 2013, s. 82.

2 Sprawa 730/79, Philip Morris v. Komisja, ECLI:EU:C:1980:209, pkt 11. 
W tym samym wyroku TSUE określił standard spoczywającego na Komisji obowiązku dowodowego związanego z wykazaniem wpływu pomocy na handel wewnątrzunijny. Orzekł, że Komisja nie popełniła błędu, nie przeprowadzając szczegółowej oceny rzeczywistego wpływu ocenianego środka wsparcia na handel między państwami członkowskimi i na konkurencję, a opierając swoje stanowisko na takich okolicznościach jak prowadzenie przez beneficjenta działalności eksportowej i przeznaczenie pomocy na wzrost jego mocy produkcyjnych.

Późniejsze orzecznictwo doprecyzowało, że brak obowiązku szczegółowej analizy wpływu środka na handel i konkurencję nie oznacza, iż KE nie musi odnieść się do tej kwestii w decyzji. Stosownie do orzeczenia w sprawie Holandia i Leeuwarder Papierwarenfabriek B.V. v. Komisja:

nawet jeśli same okoliczności, w których pomoc została udzielona, wystarczają, by wykazać, że pomoc jest zdolna wpłynąć na handel między państwami członkowskimi lub zakłócić konkurencję, Komisja musi przynajmniej wskazać te okoliczności w uzasadnieniu do decyzji³ .

Podejście oparte na szerokiej koncepcji wpływu pomocy na handel między państwami członkowskimi było kontynuowane w kolejnych wyrokach. W sprawie Tubemeuse TSUE nie zgodził się z argumentem rządu belgijskiego, jakoby liczne udzielone przezeń środki wsparcia nie miały wpływu na handel między państwami członkowskimi ze względu na to, że $90 \%$ produkcji beneficjenta eksportowano poza $\mathrm{EWG}^{4}$. Również w takich okolicznościach pomoc mogła wpłynąć na handel wewnątrzunijny i na konkurencję, biorąc pod uwagę współzależności pomiędzy rynkami, na których działały przedsiębiorstwa europejskie. Pomoc mogła też rzutować na pozycję konkurencyjną innych europejskich przedsiębiorstw działających w danym sektorze. Trybunał orzekł także, że „relatywnie mała ilość pomocy lub stosunkowo mały rozmiar przedsiębiorstwa, które ją otrzymuje, same w sobie nie wykluczają możliwości zakłócenia handlu wewnątrzwspólnotowego"5.

Z kolei w orzeczeniu w sprawie Hytasa TSUE orzekł, że do stwierdzenia wpływu pomocy na handel wewnątrzunijny nie jest konieczne, aby beneficjent sam eksportował swoje produkty. Pomoc udzielona przez państwo przedsiębiorstwu produkującemu wyłącznie na rynek wewnętrzny może bowiem prowadzić do utrzymania lub wzrostu produkcji krajowej, co może skutkować zmniejszeniem możliwości

3 Sprawy połączone 296 i 318/82, Holandia i Leeuwarder Papierwarenfabriek B.V. v. Komisja, ECLI:EU:C:1985:113, pkt 24; zob. także sprawy C-329/93, C-62-63/95, Niemcy i in. v. Komisja, ECLI:EU:C:1996:394, pkt 52; C-15/98 i C-105/99, Włochy i Sardegna Lines v. Komisja, ECLI:EU:C:2000:570, pkt 66; T-228/99 i T-233/99, Westdeutsche Landesbank Girozentrale v. Komisja, ECLI:EU:T:2003:57, pkt 292; C-409/00, Hiszpania v. Komisja,, ECLI:EU:C:2003:92, pkt 74; C-351/98, Hiszpania v. Komisja, ECLI:EU:C:2002:530, pkt 58; C-372/97, Włochy v. Komisja, ECLI:EU:C:2004:234, pkt 71.

4 Sprawa C-142/87, Belgia v. Komisja (Tubemeuse), ECLI:EU:C:1990:125.

5 Ibidem, pkt 35,40 i 43; por. sprawy C-278-280/92, Hytasa, ECLI:EU:C:1994:325, pkt 42; T-214/95, Het Vlaamse Gewest v. Komisja, ECLI:EU:T:1998:77, pkt 48. 
eksportu konkretnych produktów na rynek tego państwa ${ }^{6}$. Omawiany warunek spełniony jest zatem, nawet gdy beneficjent prowadzi działalność wyłącznie na rynku krajowym, ale spotyka się na nim z konkurencją ze strony przedsiębiorstw prowadzących działalność na rynkach europejskich.

Szeroki zakres warunku wpływu na handel między państwami członkowskimi UE oraz relatywnie niskie wymogi dowodowe stawiane KE sprawiały, że był on przez nią oceniany w sposób pobieżny, a jego spełnienie rzadko było kwestionowane $^{7}$. Aż do początku XXI wieku Komisja, co do zasady, nie podejmowała decyzji o uznaniu określonego środka za pozbawiony wpływu na handel wewnątrzunijny. Jak słusznie stwierdziła L. Hancher, takie podejście względem oceny spełnienia omawianego warunku zakładało, że środek, który udzielony został w wyniku interwencji państwa lub przy użyciu zasobów państwowych i który skutkuje przyznaniem selektywnej korzyści, wchodzi prima facie w zakres art. 107 ust. 1 TFUE $^{8}$.

\section{Podejście „popytowe” w praktyce Komisji Europejskiej}

Początek nowego stulecia zaowocował zmianą praktyki KE odnośnie do oceny spełnienia omawianego kryterium. Pierwsza decyzja znamionująca to odmienne podejście została wydana w sprawie wsparcia przekazywanego przez niemieckie władze lokalne na działalność basenu w Dorsten ${ }^{9}$. Komisja wzięła pod uwagę argumenty Niemiec, jakoby placówka nie była w stanie przyciągać klientów zagranicznych, a jego użytkownikami byli mieszkańcy Dorsten i okolic w promieniu 50 kilometrów, w całości położonych na terenie Niemiec. Komisja uznała, że podlegające jej ocenie wsparcie nie wpływało na handel między państwami członkowskimi UE, a tym samym nie stanowiło pomocy państwa.

Decyzja ta zapoczątkowała serię kilkudziesięciu podobnych rozstrzygnięć Komisji, dotyczących między innymi finansowania działalności: muzeów i obiektów

${ }^{6}$ Sprawa C-278-280/92, Hytasa, ECLI:EU:C:1994:325, pkt 40; podobnie: C-75/97, Belgia v. Komisja (Maribel), ECLI:EU:C:1999:311, pkt 47.

7 Zob. B. Kurcz, Między ustami a brzegiem pucharu... gdzie jest pomoc państwa? Definicja pomocy państwa w świetle orzecznictwa ETS-u, [w:] Pomoc państwa. Wybrane zagadnienia, red. B. Kurcz, Warszawa 2009, s. 16.

${ }^{8}$ L. Hancher, Towards a new definition of state aid under European law: Is there a new concept of aid emerging, „The European State Aid Law Quarterly” (dalej: EStAL) 2003, nr 3, s. 365.

9 Decyzja Komisji, N 258/00 — Deutschland Freizeitbad Dorsten (Dz.U. C 172 z 16.06.2001). 
kultury $^{10}$, wydarzeń i innych działań kulturalnych ${ }^{11}$, domów opieki ${ }^{12}$, szpitali ${ }^{13}$, obiektów sportowych i rekreacyjnych ${ }^{14}$, centrów konferencyjnych ${ }^{15}$, lokalnych portali wymiany informacji ${ }^{16}$, a nawet portów lotniczych i morskich ${ }^{17}$.

W decyzjach Komisja koncentrowała się na pomijanej w orzecznictwie TSUE kwestii obszaru, z którego pochodzili nabywcy określonych towarów lub usług oferowanych przez beneficjentów wsparcia. Czyniła tak, mimo że zgodnie z linią orzeczniczą zapoczątkowaną w sprawie Philip Morris weryfikacja wpływu pomocy na handel wewnątrzunijny powinna skupiać się na analizie podażowej strony rynku, a w szczególności na odpowiedzi na pytanie, czy podobna działalność wykonywana jest przez przedsiębiorstwa konkurujące w ramach takiego handlu. Podejście KE trudno było zatem uznać za mające umocowanie w judykaturze TSUE. Jest ono w związku $\mathrm{z}$ tym krytykowane zarówno z powodu stosowania nieznanego orzecznictwu kryterium odnoszącego się do strony popytowej rynku, jak i lekceważenia kryterium wpływu pomocy na konkurentów beneficjenta ${ }^{18}$.

10 Decyzje Komisji: N 630/2003, Lokalne muzea - Sardynia (Dz.U. C 275 z 8.11.2005); SA.34466, Cypr - Center for Visual Arts and Research (Dz.U. C 1 z 4.01.2013); SA.36581, Grecja - Budowa Muzeum Archeologicznego, Messara, Kreta (Dz.U. C 353 z 3.12.2013); SA.35909, Republika Czeska - Infrastruktura na rzecz turystyki (NUTS II region potudniowo-wschodni) (Dz.U. C 306 z 22.10.2013); SA.34891, Polska - Wsparcie państwa na rzecz Związu Gmin Fortecznych Twierdzy Przemyśl (Dz.U. C 293 z 9.10.2013); NN 136a/2003, Francja - Fundusze dla Ecomusée d'Alsace (Dz.U. C 96 z 29.04.2003); N 377/2007, Wsparcie dla Bataviawerf [niepublikowana].

11 Decyzje Komisji: N 257/2007, Dotacje na produkcje teatralne w kraju Basków (Dz.U. C 173 z 26.07.2007); N 458/2004, Editorial Andaluza Holding (Dz.U. C 131 z 28.05.2005); SA.33243, Jornal da Madeira (Dz.U. C 16 z 19.01.2013).

12 Decyzja Komisji SA.34576, Portugalia - Pótnocno-wschodnia jednostka opieki dtugoterminowej im. J. Piageta (Dz.U. C 3 z 13.03.2013).

13 Decyzje Komisji: N 543/2001, Irlandia - Ulgi kapitałowe dla szpitali (Dz.U. C 154 z 28.06.2002); SA.37432, Republika Czeska - Dofinansowanie szpitali publicznych $w$ regionie Hradec Králové (Dz.U. C 203 z 19.06.2015); SA.37904, Niemcy - Domniemana pomoc państwa na rzecz centrum medycznego w Durmersheim (Dz.U. C 188 z 5.06.2015); SA.38035, Niemcy - Domniemana pomoc państwa na rzecz specjalistycznej kliniki rehabilitacyjnej ze specjalnościa w ortopedii i chirurgii urazowej (Dz.U. C 188 z 5.06.2015).

14 Decyzje Komisji: N 258/00, Deutschland Freizeitbad Dorsten [niepublikowana]; C 10/2003, Niderlandy - porty rekreacyjne nienastawione na zysk (Dz.U. L 34 z 6.02.2004); SA.37963, Zjednoczone Królestwo - domniemana pomoc państwa na rzecz Glenmore Lodge (Dz.U. C 277 z 21.08.2015); SA.38208, Zjednoczone Królestwo - domniemana pomoc państwa na rzecz brytyjskich klubów golfowych będących własnością ich członków (Dz.U. C 277 z 21.08.2015).

15 Decyzja Komisji N 486/2002, Szwecja - sala kongresowa $w$ Visby (Dz.U. C 75 z 27.03.2003).

16 Decyzja Komisji SA.33149, Niemcy - Domniemana niezgodna z prawem pomoc państwa na rzecz Städtische Projekt ,, Wirtschaftsbür Gaarden”-Kilonia (Dz.U. C 188 z 5.06.2015).

17 Decyzje Komisji: SA.38441, Zjednoczone Królestwo - połaczenia lotnicze z wyspami Scilly (Dz.U. C 5 z 9.01.2015); SA.39403, Niderlandy - Inwestycja w port w Lauwersoog (Dz.U. C 259 z 7.08.2015); SA.42219, Niemcy - Remont nabrzeża Schuhmachera w porcie w Maasholm (Dz.U. C 426 z 18.12.2015).

18 Por. m.in. C. Arhold, The case law of the European Court of Justice and the court of first instance on state aids in 2005/2006 (part 1), EStAL 2006, nr 2, s. 230; C. Dekker, The "effect on 
Nie oznacza to jednak, że w tym okresie Komisja nie stosowała także podejścia opartego na analizie stanu konkurencji na określonym rynku. Jeden z nielicznych przykładów, w którym KE, stosując takie podejście, stwierdziła nieistnienie wpływu na handel między państwami członkowskimi UE, zawiera decyzja dotycząca wsparcia dla francuskich producentów esencji lawendy. Komisja zwróciła wówczas uwagę, że 95\% produkcji tego towaru pochodziło z Francji, co oznaczało, że oceniany środek wpływał na sprzedaż z tego kraju do innych państw członkowskich, a nie na handel między nimi ${ }^{19}$.

Analiza nowszej praktyki Komisji oraz treści wydanego przez nią w 2016 roku zawiadomienia $\mathrm{w}$ sprawie pojęcia pomocy państwa w rozumieniu art. 107 ust. $1 \mathrm{TFUE}^{20}$ pozwala na stwierdzenie, że przynamniej częściowo wzięła ona pod uwagę stawiane jej zarzuty. W zawiadomieniu tym KE wyraźnie odniosła się do kwestii wpływu środka na otoczenie konkurencyjne beneficjenta:

Komisja w wielu decyzjach uznała, w świetle określonych okoliczności sprawy, że środek miał wyłącznie lokalny wpływ i w związku z tym nie wpływał na wymianę handlową między państwami członkowskimi. W tych sprawach [...] stwierdziła w szczególności, że beneficjent dostarczał towary lub usługi na ograniczonym obszarze w granicach terytorium państwa członkowskiego $i$ istniało niewielkie prawdopodobieństwo przyciągnięcia przez niego klientów z innych państw członkowskich oraz że nie można było przewidzieć, że wpływ środka na warunki inwestycji transgranicznych lub przedsiębiorczości transgranicznej byłby większy niż marginalny ${ }^{21}$.

$\mathrm{W}$ decyzji w sprawie pomocy inwestycyjnej na renowację i przebudowę szpitala w Dahn w celu jego przerobienia na dom opieki Komisja, pomimo lokalnego zakresu działalności beneficjenta, opierając się na badaniu strony podażowej rynku, uznała, że planowana pomoc mogła wywrzeć wpływ na handel między państwami członkowskimi UE. Stwierdziła bowiem, że choć nie ma mowy o tym, aby beneficjent prowadził działalność za granicą, to istnieje duża penetracja niemieckiego rynku nieruchomości przez inwestorów zagranicznych szukających miejsc pod domy opieki lub domy spokojnej starości. Tym samym nie można było wykluczyć, że mogłoby dojść do zakłócenia handlu pomiędzy państwami członkowskimi UE ${ }^{22}$.

Analogiczne podejście zastosowała Komisja w decyzji w sprawie pomocy na promocję języka baskijskiego w cyfrowych mediach informacyjnych ${ }^{23}$. Poza

trade" between the member states' criterion: Is it the right criterion by which the Commission's workload can be managed?, EStAL 2017, nr 2, s. 163.

19 Decyzja Komisji N 243/2002, Pomoc dla producentów esencji lawendowej [niepublikowana].

20 Dz.U. C 262 z 19.07.2016, s. 1.

${ }^{21}$ Zawiadomienie w sprawie pojęcia pomocy państwa w rozumieniu art. 107 ust. 1 TFUE, pkt 196.

22 Decyzja Komisji SA 34655, Subsidy to retirement home in the city of Dahn (Rhineland-Palatinate) [niepublikowana].

23 Decyzja Komisji SA 47448, Promotion of the Basque language in digital news media [niepublikowana]. 
oceną zasięgu oddziaływania mediów objętych wsparciem KE zwróciła uwagę na nikły potencjał wpływu takiej pomocy na transgraniczne inwestycje i przedsiębiorczość ${ }^{24}$.

KE w określonych okolicznościach faktycznych stosuje zatem podejście oparte na kryterium lokalnego zakresu działalności beneficjenta. Zostało ono jednak zmodyfikowane. Uwzględnia bowiem także badanie strony podażowej rynku, nastawione na identyfikację konkurencji, jakiej w wymiarze europejskim podlega lub może podlegać beneficjent wsparcia.

\section{Wpływ na handel wewnątrzunijny w aktualnym orzecznictwie TSUE}

Lokalny wymiar działalności beneficjenta pomocy bywał nieskutecznie powoływany jako argument przemawiający za brakiem wpływu pomocy na handel między państwami członkowskimi UE w licznych sprawach pojawiających się na wokandzie TSUE w ostatnich kilkunastu latach. W wyroku w sprawie Altmark Trybunał orzekł, że spełnienie omawianego warunku nie jest uzależnione od lokalnego lub regionalnego charakteru usług transportowych, na których wykonywanie przeznaczone było wsparcie, oraz od skali działalności beneficjenta ${ }^{25}$. Efektem udzielenia pomocy może być bowiem zmniejszenie możliwości wejścia na rynek przedsiębiorstw z innych państw członkowskich, na którym działa beneficjent ${ }^{26}$. Trybunał wziął także pod uwagę, że rynek lokalnych przewozów pasażerskich, na którym działał beneficjent, był już wówczas w wielu państwach członkowskich zliberalizowany.

Podobnie orzekł w sprawie Heiser, w której uznał, że pomoc w postaci ulg podatkowych dla indywidualnych gabinetów dentystycznych jest w stanie wpłynąc na handel wewnątrzunijny, mimo że ich działalność miała wymiar lokalny. Zdaniem Trybunału nie można było bowiem wykluczyć, że lekarze stomatolodzy konkurowali ze swoimi kolegami po fachu mającymi siedzibę w innych państwach członkowskich ${ }^{27}$.

Późniejsze wyroki, w których TSUE odnosił się do kwestii wpływu na handel wewnątrzunijny stanowią kontynuację dotychczasowej linii orzeczniczej, prowadząc do jej utrwalenia i doprecyzowania. W wyroku w sprawie Eventech Ltd v. The Parking Adjudicator Trybunał podkreślił, że do spełnienia tego warunku

\footnotetext{
${ }^{24}$ Ibidem, pkt 30-31.

25 Sprawa C-280/00, Altmark, ECLI:EU:C:2003:415, pkt 28.

26 Ibidem, pkt 77, 78.

27 Sprawa C-172/03, Heiser, ECLI:EU:C:2005:130, pkt 35.
} 
nie jest konieczne, aby uprzywilejowane przedsiębiorstwa uczestniczyły w wewnątrzwspólnotowej wymianie handlowej. Jeżeli bowiem państwo członkowskie przyznaje pomoc przedsiębiorstwom, działalność krajowa może być dzięki temu utrzymana lub zwiększona z tym skutkiem, że zmniejszą się szanse wejścia na rynek tego państwa członkowskiego przedsiębiorstw mających siedzibę w innych państwach członkowskich ${ }^{28}$.

TSUE nie wykluczył zatem, że ewentualne korzyści uzyskane przez przedsiębiorstwa taksówkarskie, a wynikające z uprawnień do korzystania z pasów dla autobusów, mogą wpływać na handel wewnątrzunijny. Czynią one bowiem mniej atrakcyjnym świadczenie usług przez konkurentów należących do sektora pojazdów przeznaczonych do najmu z kierowcą. W rezultacie mogą zmniejszyć się szanse wejścia tych ostatnich na rynek ${ }^{29}$.

Analogiczny sposób rozumowania prezentowały sądy europejskie w wielu innych orzeczeniach zapadłych w ostatnich latach. W wyroku w sprawie INSP v. Azienda Napoletana Mobilità SpA TSUE uznał za prawidłowe rozumowanie Komisji zawarte w uzasadnieniu zaskarżonej decyzji, a stanowiące zwięzłą rekapitulację dotychczasowego sposobu wykładni omawianej przesłanki przez sądy europejskie:

do zakłócenia konkurencji i wywarcia wpływu na wymianę handlową między państwami członkowskimi dochodzi w takim zakresie, w jakim korzystające $\mathrm{z}$ tej pomocy przedsiębiorstwa eksportują część swej produkcji do innych państw członkowskich lub, jeżeli przedsiębiorstwa te nie prowadzą eksportu - w zakresie, w jakim produkcja krajowa jest uprzywilejowana, ponieważ pomoc ogranicza możliwości przedsiębiorstw mających siedziby w innych państwach członkowskich pod względem eksportu ich produktów na rynek (włoski) ${ }^{30}$.

Rozumowanie to jest oparte na dwuelementowym teście wpływu na handel wewnątrzunijny, odnoszącym się jednak wyłącznie do aspektu podażowego ryn$\mathrm{ku}$ - poprawy konkurencyjności beneficjenta na rynkach innych niż krajowe lub na rynku krajowym przez zmniejszenie możliwości wprowadzenia nań konkurencyjnych towarów zagranicznych.

Nowe orzecznictwo utrwaliło i doprecyzowało także dotychczasowe stanowisko dotyczące wymogów dowodowych stawianych KE odnośnie do wykazania spełnienia omawianego warunku. W kilku wyrokach Trybunał potwierdził, że w tym celu

nie jest konieczne wykazanie faktycznego wpływu pomocy na wymianę handlową między państwami członkowskimi, lecz jedynie zbadanie, czy pomoc ta może mieć wpływ na tę wymianę. Niemniej wpływ na wymianę handlową między państwami członkowskimi nie może być czysto hipotetyczny czy domniemywany. Należy zatem określić powód, dla którego rozpatrywany śro-

28 Sprawa C-518/13, Eventech Ltd v. The Parking Adjudicator, ECLI:EU:C:2015:9, pkt 67; zob. także sprawy: C-197/11, Libert $i$ in., ECLI:EU:C:2013:288, pkt 78; oraz C-150/16, Fondul Proprietatea SA v Complexul Energetic Oltenia SA, ECLI:EU:C:2017:388, pkt 32.

29 Sprawa C-518/13, Eventech, pkt 70, 71.

30 Sprawa C-659/17, INSP v. Azienda Napoletana Mobilità SpA, ECLI:EU:C:2019:633, pkt 23. 
dek może wpływać poprzez swoje przewidywalne skutki na wymianę handlową między państwami członkowskimi ${ }^{31}$.

Jednocześnie zgodnie z utrwalonym orzecznictwem okolicznością wystarczającą do wykazania wpływu na handel wewnątrzunijny jest poddanie sektora gospodarki, do której należą beneficjenci pomocy procesowi liberalizacji na poziomie unijnym. Takie stanowisko sądy europejskie wyrażały w odniesieniu między innymi do sektorów: bankowego ${ }^{32}$, elektroenergetycznego ${ }^{33}$, telekomunikacyjnego $^{34}$, transportu kolejowego ${ }^{35}$ oraz publicznego transportu drogowego ${ }^{36}$.

Orzecznictwo TSUE wyjaśniło również, że o ile analiza wpływu pomocy na handel wewnątrzunijny przeprowadzana przez Komisję nie musi być wyczerpująca i szczegółowa, o tyle państwa członkowskie są zobowiązane do szczegółowego badania spełnienia tego warunku, podobnie jak warunku zakłócenia konkurencji w odniesieniu do wykonania decyzji Komisji o zwrocie pomocy. Jak orzekł TSUE w sprawie Comitato „Venezia vuole vivere” $i$ in.:

przed przystąpieniem do odzyskania korzyści władze krajowe są bezwzględnie zobowiązane sprawdzić w każdym indywidualnym przypadku, czy przyznana korzyść była w stanie zakłócić konkurencję i wywrzeć wpływ na wewnątrzwspólnotową wymianę handlową w przypadku danego beneficjenta, gdyż w przeciwnym wypadku to dodatkowe sprawdzenie, które jest istotne dla zakwalifikowania otrzymanych w konkretnym przypadku korzyści jako pomocy państwa, nie byłoby możliwe ${ }^{37}$.

\section{Wnioski}

Analiza rozwoju judykatury sądów europejskich, a także praktyki stosowania art. 107 ust. 1 TFUE przez Komisję pozwalają na identyfikację tendencji rozwojowych wykładni przesłanki wpływu na handel wewnątrzunijny. Po pierwsze, orzecznictwo dąży do nadania omawianemu warunkowi większej autonomii względem warunku zakłócenia lub zagrożenia zakłóceniem konkurencji. Wynika to z większej uwagi, jaką przywiązuje się do analizy spełnienia każdego z tych warunków.

31 Sprawy C-211/15P, Orange v. Komisja, ECLI:EU:C:2016:798, pkt 64; C-150/16, Fondul Proprietatea, ECLI:EU:C:2017:388, pkt 29.

32 Sprawy C-148/04, Unicredito Italiano, ECLI:EU:C:2005:774, pkt 56, 57; C-222/04, Cassa di Risparmio di Firenze i in., ECLI:EU:C:2006:8, pkt 142; C-667/13, Banco Privado Português $i$ in., ECLI:EU:C:2015:151, pkt 51.

33 Sprawy C-150/16, Fondul Proprietatea,pkt34;C-706/17, Achema i in., ECLI:EU:C:2019:407, pkt 59.

34 Sprawa C-211/15P, Orange v. Komisja, pkt 65.

35 Sprawa T-630/15, Scandlines, ECLI:EU:T:2018:942, pkt 84.

36 Sprawa C-280/00, Altmark, ECLI:EU:C:2003:415, pkt 79.

37 Sprawy połączone C-71/09P, C-73/09P, C-76/09P, Comitato „Venezia vuole vivere” $i$ in., ECLI:EU:C:2011:368, pkt 115; C-659/17, INSP, pkt 28. 
Orzecznictwo TSUE w dalszym ciągu stoi na stanowisku koncepcji szerokiego zakresu warunku wpływu na handel między państwami członkowskimi. Sprzyjają temu niewielkie tylko wymogi dowodowe stawiane Komisji odnośnie do wykazania ziszczenia się tego warunku. Stosowany w orzecznictwie test sprowadza się przede wszystkim do oceny wpływu pomocy na otoczenie konkurencyjne beneficjenta, w tym do odpowiedzi na pytanie, czy prowadzi on działalność eksportową, a jeżeli nie, czy udzielona korzyść jest w stanie poprawić jego pozycję konkurencyjną względem podmiotów, które występują w handlu wewnątrzunijnym. Judykatura europejska nie dąży przy tym do wyodrębnienia katalogu szczegółowych kryteriów oceny wpływu na handel między państwami członkowskimi UE.

Konsekwencją takiego podejścia jest potencjalnie szeroki zakres kontroli sprawowanej przez Komisję nad udzielaniem pomocy przez państwa członkowskie. Przekłada się on na szeroki zakres kognicji KE, obejmujący środki wsparcia nieomal każdego typu, jeśli spełniają pozostałe warunki pojęcia pomoc państwa. Jednocześnie taka sytuacja sprzyja skuteczności prywatnoprawnego wdrażania reguł pomocy państwa. Sądy krajowe, stosując art. 108 ust. 3 TFUE, nie muszą bowiem dokonywać skomplikowanych analiz ekonomicznych w celu stwierdzenia wpływu środka na handel między państwami członkowskimi.

Inne wnioski można wyciągnąć z obserwacji praktyki Komisji. Wynika z nich, że jest ona skłonna uznawać, że korzyści kierowane na działalność o charakterze czysto lokalnym, zwykle o niewielkiej rentowności, nie wpływają na handel wewnątrzunijny. W takich przypadkach stosuje ona test oparty głównie na analizie popytowej strony rynku, od niedawna uzupełniony także oceną strony podażowej. Choć taki sposób oceny nie jest wprost sprzeczny z orzecznictwem TSUE, to do tej pory jego prawidłowość nie znajduje w nim jednoznacznego potwierdzenia. Będące jego skutkiem zawężenie zakresu pojęcia pomocy państwa przez wyłączenie spod niego korzyści kierowanych na przedsięwzięcia o lokalnym tylko zasięgu oddziaływania i niewielkiej rentowności stanowi przejaw uzasadnionego oportunizmu Komisji, działającej jako organ nadzorujący udzielanie pomocy przez państwa członkowskie. Pozwala jej skupić się na środkach powodujących najpoważniejsze zakłócenia handlu wewnątrzunijnego i konkurencji, co optymalizuje użycie ograniczonych zasobów personalnych i finansowych, którymi KE dysponuje.

\section{Bibliografia}

Arhold C., The case law of the European Court of Justice and the court of first instance on state aids in 2005/2006 (part 1), „The European State Aid Law Quarterly” 2006, nr 2.

Bacon K., EU Law of State Aid, Oxford 2013.

Dekker C., The "effect on trade" between the member states criterion: Is it the right criterion by which the Commission's workload can be managed?, „The European State Aid Law Quarterly" 2017, nr 2. 
Hancher L., Towards a new definition of state aid under European law: Is there a new concept of aid emerging, „The European State Aid Law Quarterly” 2003, nr 3.

Kurcz B., Między ustami a brzegiem pucharu... gdzie jest pomoc państwa? Definicja pomocy państwa w świetle orzecznictwa ETS-u, [w:] Pomoc państwa. Wybrane zagadnienia, red. B. Kurcz, Warszawa 2009.

Rusche T.M., Miheau C., Piffaut H., Casteele K. van de, State aid, [w:] The EU Law of Competition, red. J. Fall, A. Nikpay, Oxford 2014.

\section{Effect on trade between Member States as a condition of application of art. 107 (1) TFEU: Directions of case-law development}

\section{Summary}

The effect on trade between Member States is considered as one of the elements of the notion of State Aid within the meaning of art. 107 (1) TFEU. In the course of the development of the caselaw of the CJEU, the interpretation of this condition has evolved. The EU courts gradually devote more attention to its analysis, clarifying its meaning and even (slightly) narrowing its scope. Assessment of the condition on the effect on intra-EU trade, as applied by the CJEU, focuses on the supply side of the market - the competitive environment of the beneficiary of aid. The Commission's decision-making practice develops in a different direction. In numerous cases the Commission held that a measure does not constitute State Aid due to lack of effect on intra-European trade. The Commission has based this approach on the argument of the local scope of the activity of a beneficiary. This approach, based on the assessment of the demand side of the market, though not directly contradictory to the case-law of the CJEU, finds no support in it.

Keywords: EU Law, Rules on Competition, State aid Law, Notion of State Aid. 